\title{
The Information Content Of Loan Default Disclosures In The Prediction Of Bank Failure
}

\author{
Marilyn Waldron, (E-mail: mwaldron@business.otago.ac.nz), University of Otago, New Zealand \\ Charles Jordan, University of Southern Mississippi \\ Alan MacGregor, University of Otago, New Zealand
}

\begin{abstract}
Bank failure prediction remains an important economic issue. Although prior research investigates bank failure prediction, the opportunity to improve predictions exists. The purpose of this present study is to investigate the possibility of improving prediction of bank failure by including loan default variables and regional variation in prediction of bank failure. The results of statistical analysis indicate loan default measures contain information content both in their own right and also incrementally above that of traditional CAMEL measures. Furthermore, statistical analysis utilizing logit regression shows the superiority of bank failure prediction models that include consideration of geographic region.
\end{abstract}

\section{INTRODUCTION}

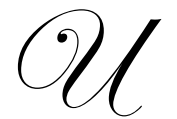

.S. history indicates that bank failures have been a recurring problem with the highest post-depression levels occurring in the late 1980's. More specifically, Amos (1992) reported for the 39-year period 1943-1981 that the average numbers of bank closings were six per year. In contrast, during the sevenyear period from 1982-1988 the average per year failure rate had increased to 115. Bank failure rates in the 1990s declined from the high level in the 1980s, and the number of failures decreased to 11 in 2002 (FDIC, 2002).

Although the number of failures may have decreased since the mid-1980s, even a single large bank failure can be catastrophic. A belief existed in the early 1980s that certain banks were considered too large to fail, but subsequent failures have proven the belief incorrect. The economic effects of bank failures have varied in levels up to billions of dollars for an individual bank e.g. \$3.86 billion First Republic Bank Corporation, 1988. (Amos, 1992).

Bank failures have continued into the new millennium along with their resulting costs. For example, the failure of Nextbank resulted in resolution costs to the FDIC of \$526 million in 2002 (FDIC, 2002), and Southern Pacific's failure caused $\$ 100$ million in resolution costs in 2003 (FDICG, 2004). Further, these FDIC resolution costs do not include additional outlays related to the layoff of workers, loss to suppliers and other related organizational costs (Altman, 1984).

As Marini (2003) notes, bank failure prediction remains an important economic issue. Given the significant losses associated with even one individual bank failure, prediction of bank failure represents a continuing and critical issue. Even the best of the existing predictive models have scope for improvement. The present research examines loan default measures, as factors for improvement in bank failure prediction.

\section{GENERAL BACKGROUND}

Previous research investigating the prediction of bank failure provides a foundation for assessment of bank health, but the bank failure models utilized in the prior studies exhibit scope for improvement. This present 
investigation focuses on three areas for improvement in prediction of bank failure: (1) whether loan default measures contain predictive information, (2) whether loan default measures exhibit incremental information relative to other measures utilized in traditional predictions, and (3) whether a regional factor contains information useful for improvement in the assessment of bank failure.

\section{Loan Default Measures and Risk}

Research exists that examines loan default measures, but no discussion has explained the logic for their inclusion in predictions of bank failure (Cole et al., 1995; Cole and Gunther, 1998; Kocagil et al., 2002; Kolari et al., 2002). An argument exists that loan default measures capture information about risk for particular assets of a bank and would thus be useful in predictions of bank failure. Sundaresan (2001) presents arguments associated with the importance of developing proxies to capture the significant, but unobservable, dimensions of risk. In relation to the utilization of loan default measures in bank failure prediction, the present research focuses on proxies for credit risk, which may additionally capture a facet of operational risk.

\section{Incremental Information Content of Loan Default Measures}

Some might present an argument that loan default measures provide little or no incremental benefit when examined in conjunction with traditional predictive measures. In contrast, an argument can be presented that loan default measures viewed in isolation do provide information to improve bank failure prediction. This present study examines the incremental information content of the loan default measures above that of traditional measures.

\section{Information Content Related to Geographic Region}

Loan default problems and any resulting bank failure can be associated with exogenous factors not under management's control, such as general economic conditions. Exogenous factors include conditions related to a particular geographic area. Each geographic region can be argued to exhibit diverse characteristics relative to other regions, related to aspects such as the type of loan concentration, regulatory setting and unique socio-economic environment.

Facets of a region's characteristics may have an impact on the number of bank failures. Prior research (Barth et al., 1990) examines region as a factor in bank failure prediction, but results have been inconclusive. Gaining an understanding of the effects of regional influences on bank failure prediction may enhance the effectiveness of models for prediction of bank failure.

\section{LOAN DEFAULT: INTUITION, THEORY, AND HISTORICAL AND RESEARCH EVIDENCE}

At least four sources provide support for the contention that loan default measures may improve the prediction of bank failure. First, intuitively, improvements in predictions could be obtained through the inclusion of information related to loan default, as loans represent a bank's largest asset. If risk develops during the collection of a bank's loans, a greater probability of weakness and failure evolves. Several arguments exist to support this intuitive view.

\section{Theoretical Support}

Berger et al. (1991) propose that adjustments to risk-based capital specifically for loan default disclosure would increase the accuracy of capital adequacy requirements. In theory, credit losses and the related loan default disclosures would correlate with the bank's capital requirements to enrich the understanding of inherent risk. In the capacity of a proxy for risk, loan default information could prove useful in the prediction of bank soundness.

Theoretically, information about post-contract default risk commensurate with loans would be expected to provide information for assessment of at a minimum a bank's credit risk and subsequently assist in assessment of overall financial health. More specifically, loan default measures provide loss information in the form of evidence 
about a bank's willingness and ability to deal with loan default problems, which essentially represents a banks' involvement in credit risk management and indirectly relates to operational risk. The occurrence of risk relates to post-contracting events, where a debtor's repayment is less than the contract amount and is contingent on unknown, unfavorable and uncontrollable outcomes. The resulting risk relates not only to individual credit loan risk, but also affords evidence of management's attitudes toward risk.

Reported loan default disclosures that contain differing levels of discretion include non-accruing loans, past due loans, loan loss reserves, loan loss provisions and net loan charge-offs. Milne (2002) supports the idea of discretion, indicating that management has both the incentive and capacity to control loan portfolio risk. In any given time period, managers have discretion in both the amount charged for loan loss provisions and the amount of loans written off. In comparison, managers possess relatively limited discretion to affect the level of non-performing loans.

\section{Historical Evidence}

Historical evidence from the circumstances surrounding the proliferation of bank failures in the 1980's provides further motivation for including loan default risk factors in bank failure prediction models. A review of bank failure literature by Looney et al. (1989) reports that major factors associated with bank failures relate to loan losses, such as in deteriorating loan quality or poor loan/collection policies. Various loan related factors recur as a theme in explanation of failure.

\section{General Research Evidence}

In general, research related to bank failure prediction has occurred through assessment of the usefulness of various financial measures (e.g., see Meyer and Pifer, 1970; Sinkey 1975; Martin, 1977; Sinkey, 1978; Pettway and Sinkey, 1980; West, 1985; Lane et al., 1986; Looney et al., 1989; Espahbodi, 1991; Thomson, 1991; Whalen, 1991; Amos, 1992; Tam and Kiang, 1992; Cole et al., 1995; Cole and Gunther, 1998; Kocagil et al., 2002; Kolari et al., 2002). The factors examined include measures of loan default disclosure with utilization of a range of statistical analysis methods. The reported results indicate inconclusive findings concerning the usefulness of loan default disclosures.

Research tests the usefulness of loan default information for predictions of failure with utilization of several measures including the following: a ratio of provision for loan losses to operating expense (Sinkey, 1978); net loan recoveries to total loans, provision for loan losses to total operating expense and gross loan charge-offs to net income plus provisions for loan losses (Lane, 1986); a ratio of reserves for possible loan losses to total loans (Espahbodi, 1991); provision for loan losses to average loans and net charge-offs to average loans (Tam and Kiang, 1992) net loan charge-offs to total assets and provision for loan losses to total assets (Kolari et al., 2002). The researchers provide no evidence to support the contention that the loan default measures improve predictions of bank failure.

Although the results from the above researchers did not confirm the usefulness of loan default measures in prediction of failure, other studies did provide preliminary empirical support. Research findings of bank failure prediction that maintain the usefulness of loan default measures include the following variations: non-performing loans (West, 1985); total loans 90 days or more past due to net loans and leases and total non-accruing loans and leases to net loans and leases (Tam and Kiang, 1992); ratio of loans past due by 90 days or more plus non-accrual loans plus other real estate owned assets to gross assets (Cole and Gunther, 1995); past due loans, non-accruing loans, reserves for loan and lease losses, provisions for loan and lease losses and net charge-offs (Cole et al., 1995); past due loans and non-accruing loans (Cole and Gunther, 1998); allowance for loan losses to total assets (Kolari et al., 2002); and commercial charge-offs and installment charge-offs (Kocagil et al., 2002).

In light of the incomplete and varying results in the aforementioned research and given the importance of risk to the evaluation of financial health, the present research examines the extent that measures of loan default can provide utility in the prediction of bank failure and whether they exhibit incremental information above traditional measures. 


\section{BACKGROUND: CAMEL MODELS}

Bank failure prediction models generally contain traditional measures represented in the terminology of CAMEL. The FDIC's development of CAMEL originally occurs for the purpose of determining when to schedule on-site examination of a bank (Thomson, 1991; Whalen and Thomson, 1988). The majority of prior research for prediction of bank failure focuses on capturing information representative of capital adequacy (C), asset quality (A), management quality (M), earnings (E) and liquidity (L), where the combination of the five is designated as a CAMEL model.

The five CAMEL factors indicate the increased likelihood of bank failure when any of the five factors embodied in CAMEL prove inadequate. Although researchers have a common adherence to the broad guidelines available in the CAMEL criteria, previous studies for predictions of bank failure contained no consistent set of CAMEL measures. The general choice of the five CAMEL factors occurs based on the theory that each represents a major element in a bank's financial statements. For example, one of these threats represented in CAMEL exists in the loss of assets (A). Short-term liquid assets (L) aid in covering loan payment defaults and offset the threat of losses or large withdrawals that might occur. The following research provides explanations for choice of CAMEL measures: Lane et al. (1986), Looney et al. (1989), Elliott (1991), Eccher et al. (1996), Thomson (1991) and Estrella et al. (2000).

\section{Hypotheses}

In this present study, assessment of the information content of CAMEL and the loan default measures occurs in three stages. The first stage relates to determining the information content of loan default measures without the influence of other measures, such as those in CAMEL. A primary component of the loan default measures, nonperforming loans, is comprised of past due loans (90 days or more past due) and non-accruing loans (loans on which interest is no longer being accrued). In terms of discretion, these two measures of non-performing loans represent perhaps the most rigid measure of loan default risk, as there exists little room for management's judgment in determining the amount to be recorded. For example, when a loan becomes 90 days past due, it is automatically classified as a component of non-performing loans. No judgement exists for management in the determination of the amount.

Theoretically, these two variables would be relatively more consistent in measurement between all banks due to lack of the aforementioned discretion. The other loan default measures include loan loss provisions, loan chargeoffs and loan loss reserves. These three measures exhibit a higher level of discretion relative to the other loan default measures. A manager must determine and record a reasonable amount for these loan default measures, but no consistent cut off time period exists for determination of the amount.

The first hypothesis in the present research tests the following:

H1: Loan default measures provide information content for the prediction of bank failure.

An increase in the magnitude of the loan default measures theoretically signals a greater likelihood of bank failure. Thus, in a logit model to predict bank failure, a positive coefficient is expected for all of these variables.

The second hypothesis examines the incremental information content of the loan default measures above that contained in general measures in published financial statements. Examination of the additive value of these measures leads to the second hypothesis, which states:

H2: Loan default measures contain incremental information content for prediction of bank failure in relation to CAMEL measures.

Tests of the second hypothesis occur with inclusion of a ratio for each of the CAMEL measures. Appendix A contains a summary of the definitions for the CAMEL factors examined. 
The signs of the coefficients for measures of capital adequacy, management quality, earnings and liquidity in the CAMEL model are expected to be negative. As each of these measures decreases, the likelihood of failure increases. Expectations exist for the measure of assets to exhibit a positive relationship with failure. Since the asset measure (A) represents those loans that normally exhibit higher risk, an increase in that type of loan concentration (i.e., commercial and industrial loans) translates into a higher probability of failure.

Examined exogenous factors consist of inter-temporal and regional aspects. A priori, inter-temporal and regional differences could be expected to correlate with predictions of bank failure. Correlation would occur given the notion that these two factors link to economic problems intertwining time and regional economic concentrations. Sudarsanam and Taffler (1995) note that a financial ratio provides information related to economic conditions and varies as the economy fluctuates. In an examination of regional effects utilizing a dummy variable for state, Barth $e t$ al. (1990) provide evidence that region has insubstantial statistical significance in tobit estimations for the cost of resolution.

This current research examines inter-temporal effects tested singly with resulting significance. However, in further analysis with testing for the predictive ability for the combination of both inter-temporal and regional factors, the inter-temporal factor proved insignificant. Further testing eliminated the inter-temporal factor in predictions based on the statistical evidence and the argument that the failures relate more closely to an aspect of a particular industry, geographic region or other economic factors. For example, if the agricultural industry experiences a general downturn, the banks in that specific region that have issued a greater number of agricultural loans face a greater probability of failure. As an increasing number of farmers in the specific region experience unprofitable operations, a snowball effect would intensify the outcome for a bank in that region.

The third and final hypothesis tests regional differences as follows:

H3: Loan default disclosure measures contain information content for prediction of bank failure in regional models.

\section{Sample}

The failed banks included in the sample were identified from a FDIC listing for the time period 1985-1991. The sample includes 535 failed banks with each failed bank matched with a non-failed bank. Nine hundred fifty four banks from the total sample (477 failed banks and 477 non-failed banks) are utilized in the development sample. The holdout sample contains the remaining 116 banks (58 failed and 58 non-failed banks) from the 1991 time period. The time period (i.e., 1985-1991) is chosen for study because of the significant number of bank failures occurring during these few years. That is, a large data base of failed banks exist within a relatively short time period, which eliminates a portion of the noise that might exist in a model developed with bank failures over an extended period of time.

The financial information for the 1070 banks is collected from Sheshunoff"s Bank collection, based on the preliminary year-end Reports of Condition and Reports of Income available from the FDIC. Collection of the financial data for each bank in the development sample contains data for one year prior to the prediction year. For the holdout sample, the sample includes data for one and two years prior to prediction. The data collected for each selected bank included a ratio for each of the loan default measures and the CAMEL factors chosen. Failed banks are defined as those that bank regulators deem as no longer viable and, therefore, subsequently are closed.

Often previous development of prediction models occurs with data samples limited to one state or one geographic region of the U. S. The current broad sample is comprised of relatively non-homogenous banks chosen from different states and regions in the U.S. As such, the banks in the sample contained a variety of types of loan concentrations including industrial, real estate, oil and gas and agricultural loans.

The development sample contains banks from six regions of the U.S. (i.e., Southwest, Southeast, Midwest, Rocky Mountain, West and Northeast). The holdout sample of 58 failed banks and 58 non-failed banks are from states in the southwestern U.S. 
All predictive models include failed and non-failed banks, where a matching process occurs on the basis of asset size and state. The matched pair research design adds certain advantages. Although collection of matched samples generally entails more cost, the research design controls for extraneous variables, which may be known or unknown (Lee and $\mathrm{Li}, 1993$ ). It also allows a closer investigation of the characteristic problems under investigation, as the sample includes a higher number of observations for the characteristic (i.e., bank failure) under study than would a sample that is proportional to the population.

One view exists that criticizes a matched pairs design and purport the use of a sample based on the population proportions. In this current study, additional formulation and analysis to examine a population based conflict in views is performed. Details of the additional analysis are available from the authors.

\section{Method}

Evaluation in support of loan default usefulness in assessment of bank failure transpires with application of logistic regression. Logit regression assesses a binary dependent variable, such as failed or non-failed bank and typically produces a curvilinear response with an asymptotic ( 0 and 1$)$ function. The resulting logistic function can be linearized through a logistic transformation with little difficulty.

The method allows the probability of an event, such as bank failure, to be estimated (Neter et al., 1985) using the maximum-likelihood method (Norusis, 2002). The resulting choice results in the most probable or likely outcome.

The errors resulting from the comparison can be classified into Type 1 and Type II errors. A trade-off exists between Type I errors (the error made in wrongly predicting that a bank will not fail) and Type II errors (the error made in wrongly predicting that a bank will fail). Type I errors normally exhibit a higher possibility of losses (i.e., costs) than Type II errors. Thus, in development of models for prediction, a common objective is to decrease the level of Type I errors, although a trade off with the Type II errors typically occurs.

As noted, logit provides a score, typically between zero and one, which indicates the likelihood of the predicted state (failed or nonfailed bank). Often, a cut off of .5 is chosen for classification. However, as noted by Cole et al. (1995), cut offs other than the midpoint are useful for achieving high classification accuracies for identifying problems, in this case problem banks. More specifically, lowering the cut off below .5 results in identifying more failed banks correctly, but at the cost of classifying more non-failed banks as failed.

\section{Results}

Table 1 exhibits the range, mean and standard deviation for the loan default measures, CAMEL measures and total assets. The measures representative of asset quality (AA), management quality (MAN) and liquidity (LIQUID) exhibit greater variability, as evidenced by the higher standard deviations.

Table 1: Descriptive Statistics

\begin{tabular}{|c|c|c|c|c|}
\hline Variable & Minimum & Maximum & Mean & Std Deviation \\
\hline CAPAD & -8.90 & 29.78 & 7.6513 & 4.4371 \\
AA & .00 & 4.21 & 24.6600 & 31.4400 \\
MAN & -19.30 & 209.10 & 14.4538 & 27.3448 \\
EARN & -39.00 & 13.80 & -1.6713 & 3.8138 \\
LIQUID & -692.37 & 94.32 & 40.5934 & 28.2644 \\
PROV & -1.31 & 400.00 & 4.4676 & 13.6400 \\
NCO & -1.00 & 29.40 & 3.6796 & 4.3077 \\
NONACC & .00 & 48.40 & 5.4037 & 6.2357 \\
PASTDUE & .00 & 102.00 & 2.4564 & 4.6051 \\
RES & .00 & 36.20 & 2.5966 & 2.7899 \\
\hline
\end{tabular}




\begin{tabular}{|c|c|c|}
\hline CAPAD & $=$ & (Equity Capital + loan loss reserves)/total assets x 100 \\
\hline AA & $=$ & Commercial and industrial loans/total loans x 100 \\
\hline MAN & $=$ & Percent change in loans during the past 5 years \\
\hline EARN & $=$ & Income before securities gains and losses/average total assets x 100 \\
\hline LIQUID & $=$ & {$[($ Total assets-total loans)/total assets $] \times 100$} \\
\hline PROV & $=$ & Loan loss provision /average loans x 100 \\
\hline $\mathrm{NCO}$ & $=$ & Net charge-offs of loans/average loans x 100 \\
\hline PASTDUE & $=$ & Loans 90 days or more past due/ total loans x 100 \\
\hline NONACC & $=$ & Loans on which interest is no longer accrued/total loans $\mathrm{x} 100$ \\
\hline RES & $=$ & Loan loss reserve/total loans x 100 \\
\hline
\end{tabular}

Table 2 provides the Spearman correlation coefficients indicating failure appears significantly correlated with each of the loan default and CAMEL measures. The majority of the coefficients exhibit significance at an alpha level of .000. Capital adequacy exhibits the highest correlation (-.815) with the measure of failure, followed by the measure of earnings (-.771) and net charge-offs (.637). Examination of the correlations for the independent measures indicates no serious collinearity.

Table 2: Spearman's Correlation Coefficients (Rho) For Loan Default and Camel Measures

\begin{tabular}{|c|c|c|c|c|c|c|c|c|c|c|c|c|}
\hline \multirow{2}{*}{ FAIL } & \multirow{3}{*}{$\begin{array}{l}\text { Rho } \\
\text { Sig. }\end{array}$} & \multirow{2}{*}{$\begin{array}{l}\text { FAIL } \\
1.000\end{array}$} & \multirow{2}{*}{$\begin{array}{c}\text { CAPAD } \\
-0.815\end{array}$} & \multirow{2}{*}{$\begin{array}{c}\text { AA } \\
0.299\end{array}$} & \multirow{2}{*}{$\begin{array}{l}\text { MAN } \\
-0.321\end{array}$} & \multirow{2}{*}{$\begin{array}{l}\text { EARN } \\
-0.771\end{array}$} & \multicolumn{3}{|c|}{ LIQUID NONACC PASTDUE } & \multirow{2}{*}{$\begin{array}{l}\text { RES } \\
0.182\end{array}$} & \multirow{2}{*}{$\begin{array}{r}\text { PROV } \\
0.567\end{array}$} & \multirow{2}{*}{$\begin{array}{l}\text { NCO } \\
0.637\end{array}$} \\
\hline & & & & & & & -0.499 & 0.590 & 0.309 & & & \\
\hline & & & 0.000 & 0.001 & 0.000 & 0.000 & 0.000 & 0.000 & 0.001 & 0.050 & 0.000 & 0.000 \\
\hline \multirow[t]{2}{*}{ CAPAD } & Rho & & 1.000 & -0.153 & 0.323 & 0.715 & 0.406 & -0.540 & -0.240 & -0.137 & -0.459 & -0.597 \\
\hline & Sig. & & & 0.101 & 0.000 & 0.000 & 0.000 & 0.000 & 0.010 & 0.141 & 0.000 & 0.000 \\
\hline \multirow[t]{2}{*}{ AA } & Rho & & & 1.000 & -0.043 & -0.229 & -0.216 & 0.171 & 0.013 & -0.039 & 0.136 & 0.097 \\
\hline & Sig. & & & & 0.650 & 0.014 & 0.020 & 0.067 & 0.891 & 0.677 & 0.147 & 0.302 \\
\hline \multirow[t]{2}{*}{ MAN } & Rho & & & & 1.000 & 0.272 & -0.201 & -0.319 & -0.105 & -0.080 & -0.146 & -0.207 \\
\hline & Sig. & & & & & 0.003 & 0.030 & 0.000 & 0.260 & 0.393 & 0.118 & 0.026 \\
\hline \multirow[t]{2}{*}{ EARN } & Rho & & & & & 1.000 & 0.422 & -0.572 & -0.268 & -0.319 & -0.708 & -0.698 \\
\hline & Sig. & & & & & & 0.000 & 0.000 & 0.004 & 0.000 & 0.000 & 0.000 \\
\hline \multirow[t]{2}{*}{ LIQUID } & Rho & & & & & & 1.000 & -0.275 & -0.185 & -0.150 & -0.279 & -0.260 \\
\hline & Sig. & & & & & & & 0.003 & 0.047 & 0.109 & 0.002 & 0.005 \\
\hline \multirow[t]{2}{*}{ NONACC } & Rho & & & & & & & 1.000 & 0.261 & 0.423 & 0.380 & 0.482 \\
\hline & Sig. & & & & & & & & 0.005 & 0.000 & 0.000 & 0.000 \\
\hline \multirow[t]{2}{*}{ PASTDUE } & Rho & & & & & & & & 1.000 & 0.147 & 0.348 & 0.284 \\
\hline & Sig. & & & & & & & & & 0.114 & 0.000 & 0.002 \\
\hline \multirow[t]{2}{*}{ RES } & Rho & & & & & & & & & 1.000 & 0.292 & 0.241 \\
\hline & Sig. & & & & & & & & & & 0.001 & 0.009 \\
\hline \multirow[t]{2}{*}{ PROV } & Rho & & & & & & & & & & 1.000 & 0.854 \\
\hline & Sig. & & & & & & & & & & & 0.000 \\
\hline \multirow[t]{2}{*}{$\mathrm{NCO}$} & Rho & & & & & & & & & & & 1.000 \\
\hline & Sig. & & & & & & & & & & & \\
\hline
\end{tabular}

In testing hypothesis one concerning the loan default measures, a logit model is developed for a comprehensive group of loan loss measures. Table 3 (Panel A) presents the summary statistics and indicates that the model's in-sample classification accuracy is $85 \%$. With the exception of the loan loss reserves (RES), all of the components of loan default disclosure in the model exhibit statistical significance (.05 level) and the expected sign for the coefficient. Subsequent models eliminate the loan loss reserve measure from testing. 
Table 3: Tests of Hypotheses: Logit Models For Development Sample

\begin{tabular}{|c|c|c|c|c|}
\hline Variable & Coefficient & S.E. & Sig & $\begin{array}{c}\text { Classification } \\
\text { Accuracy }\end{array}$ \\
\hline $\begin{array}{c}\text { A. } \\
\text { NONACC } \\
\text { PASTDUE } \\
\text { RES } \\
\text { PROV } \\
\text { NCO } \\
\text { Constant }\end{array}$ & $\begin{array}{c}.2814 \\
.1382 \\
.0546 \\
.2864 \\
.1334 \\
-2.9652\end{array}$ & $\begin{array}{l}.0327 \\
.0402 \\
.0845 \\
.0716 \\
.0650 \\
.2075\end{array}$ & $\begin{array}{l}.0000 \\
.0006 \\
.5186 \\
.0001 \\
.0402 \\
.0000\end{array}$ & $85.0 \%$ \\
\hline $\begin{array}{c}\text { B. } \\
\text { CAPAD } \\
\text { AA } \\
\text { MAN } \\
\text { EARN } \\
\text { LIQUID } \\
\text { Constant }\end{array}$ & $\begin{array}{c}-.6719 \\
.0163 \\
-.0139 \\
-.8108 \\
-.0810 \\
7.8098\end{array}$ & $\begin{array}{l}.0795 \\
.0045 \\
.0058 \\
.0908 \\
.0124 \\
.8397\end{array}$ & $\begin{array}{l}.0000 \\
.0003 \\
.0167 \\
.0000 \\
.0000 \\
.0000\end{array}$ & $91.6 \%$ \\
\hline $\begin{array}{c}\text { C. } \\
\text { CAPAD } \\
\text { AA } \\
\text { MAN } \\
\text { EARN } \\
\text { LIQUID } \\
\text { PROV } \\
\text { NCO } \\
\text { PASTDUE } \\
\text { NONACC } \\
\text { Constant }\end{array}$ & $\begin{array}{c}-.7410 \\
.0220 \\
-.0085 \\
-.3317 \\
-.1049 \\
.2714 \\
.1835 \\
.0516 \\
.1509 \\
7.3365 \\
\end{array}$ & $\begin{array}{l}.8680 \\
.0051 \\
.0066 \\
.1049 \\
.0149 \\
.1013 \\
.1161 \\
.0194 \\
.0406 \\
.9238 \\
\end{array}$ & $\begin{array}{l}.0000 \\
.0000 \\
.1987 \\
.0016 \\
.0000 \\
.0074 \\
.1139 \\
.0078 \\
.0002 \\
.0000 \\
\end{array}$ & $93.2 \%$ \\
\hline
\end{tabular}

$\begin{array}{lll}\text { NONACC } & = & \text { Loans where interest is no longer accrued/total loans } \times 100 \\ \text { PASTDUE } & = & \text { Loans } 90 \text { days or more past due/ total loans x } 100 \\ \text { RES } & = & \text { Loan loss reserve/total loans } \times 100 \\ \text { PROV } & = & \text { Loan loss provision /average loans } \times 100 \\ \text { NCO } & = & \text { Net charge-offs of loans/average loans x 100 } \\ \text { CAPAD } & = & \text { (Equity Capital + loan loss reserves)/total assets x 100 } \\ \text { AA } & = & \text { Commercial and industrial loans/total loans x 100 } \\ \text { MAN } & = & \text { Percent change in loans during the past 5 years } \\ \text { EARN } & = & \text { Income before securities gains \& losses/average total assets x } 100 \\ \text { LIQUID } & = & {[(\text { Total assets-total loans)/total assets] } \times 100}\end{array}$

Table 3 (Panel B) presents the results of logit regression for a traditional CAMEL model, as a benchmark and initial step in testing hypothesis two. All measures exhibit significance at the .05 level or better with correct signs for each coefficient. The model yields an in-sample classification accuracy of $91.6 \%$.

The next step in the examination of the incremental information content of loan default factors involve tests for the model containing the traditional CAMEL variables supplemented by the loan default measures. Table 3 (Panel C) presents the results of the expanded model with traditional CAMEL measures supplemented by the loan default measures. The result presents in-sample classification accuracy of $93.2 \%$ with the signs of all coefficients as expected. All variables exhibit significance with the exception of the measures representative of management (MAN) and net charge-offs (NCO).

One explanation for the insignificance of NCO relates to relative levels of discretion, where management is likely to have relatively more discretion over the amount of loan charge-offs recorded in a given period compared to other loan default measures. The result is that the manager's discretion obscures the information content of net 
charge-offs. For example, management of one bank might have a firm policy of charging off any loans over 180 days past due, while management of another bank may have no set policy for when to write off loans, but rather makes the decision on a loan-by-loan basis. Thus, more "noise" exists in the form of other factors (policy) in arriving at the reported amounts of $\mathrm{NCO}$ and, therefore, it is more difficult to model discriminatory power.

A chi-square test of the difference in the model's predictive accuracy with the addition of the loan default measures to the CAMEL model indicates a significant difference at the .000 level. Although the loan default measures alone provides good results $(85 \%)$ and the CAMEL model by itself provides relatively accurate prediction (91.6\%), adding the loan default measures to the CAMEL model improves the classification accuracy by a statistically significant amount. These results provide support for hypothesis two.

Subsequently, the coefficients from the development models are utilized to predict bank failure for the holdout sample. With the classification accuracy for models set at a .4 cut off, the resulting Type II error rates are relatively high at $25.86 \%$ and $22.41 \%$ for the CAMEL model and the expanded CAMEL plus loan default measures model, respectively.

Cole et al. (1995) examined the trade off between Type I and II errors for three models: a CAMEL model, FIMS (Financial Institutions Monitoring System) and UBSS (Uniform Bank Surveillance Screen) model. Their results are summarized in Table 4 for comparative purposes.

Table 4: Trade off in Type I and Type II Error Rates For Holdout Sample

A. Type II error rate equals $5 \%$

\begin{tabular}{|c|c|c|}
\hline & Type I error rate & Type II error rate \\
\hline Cole et al. (1995) & & $5 \%$ \\
\hline CAMEL & $32 \%$ & $5 \%$ \\
UBSS & $28 \%$ & $5 \%$ \\
FIMS & $20 \%$ & $5 \%$ \\
\hline Current Study & & $5 \%$ \\
CAMEL & $6.90 \%$ & 5 \\
CAMEL Plus Loan default & $3.45 \%$ & \\
\hline
\end{tabular}

\section{B. Type II error rate equals $10 \%$}

\begin{tabular}{|c|c|c|}
\hline & Type I error rate & Type II error rate \\
\hline Cole et al. (1995) & & $10 \%$ \\
\hline CAMEL & $22 \%$ & $10 \%$ \\
UBSS & $16 \%$ & $10 \%$ \\
FIMS & $9 \%$ & $10 \%$ \\
\hline Current Study & & $10 \%$ \\
CAMEL & $1.72 \%$ & $1.72 \%$ \\
CAMEL Plus Loan default & & \\
\hline
\end{tabular}

Application of the same procedure occurs in examination of the trade off between Type I and Type II error rates for the CAMEL and expanded CAMEL plus loan default measures model in this current study. The results appear in Table 4 and provide two important findings. First, at both levels of Type II errors [i.e., 5\% (Panel A) and $10 \%$ (Panel B)], the models in the current study achieve noticeably lower Type I error rates compared to that of Cole et al. (1995).

Second, and more importantly, for the models in the current study, note that at a 5\% Type II error rate (Panel A), the Type I error rate for the expanded model (containing loan default and CAMEL measures) exists at one half (i.e., 3.45\%) the level of the Type I error rate (i.e., 6.9\%) for the CAMEL model. 
Figure 1 provides a graph of the Type I and Type II errors for the predictive results from the holdout sample. The overall error rate of the CAMEL model emerges as relatively lower than the error rate for the loan default (Risk) model confirming the results from development testing.

Figure 1: Trade Off In Error Types For Holdout Sample

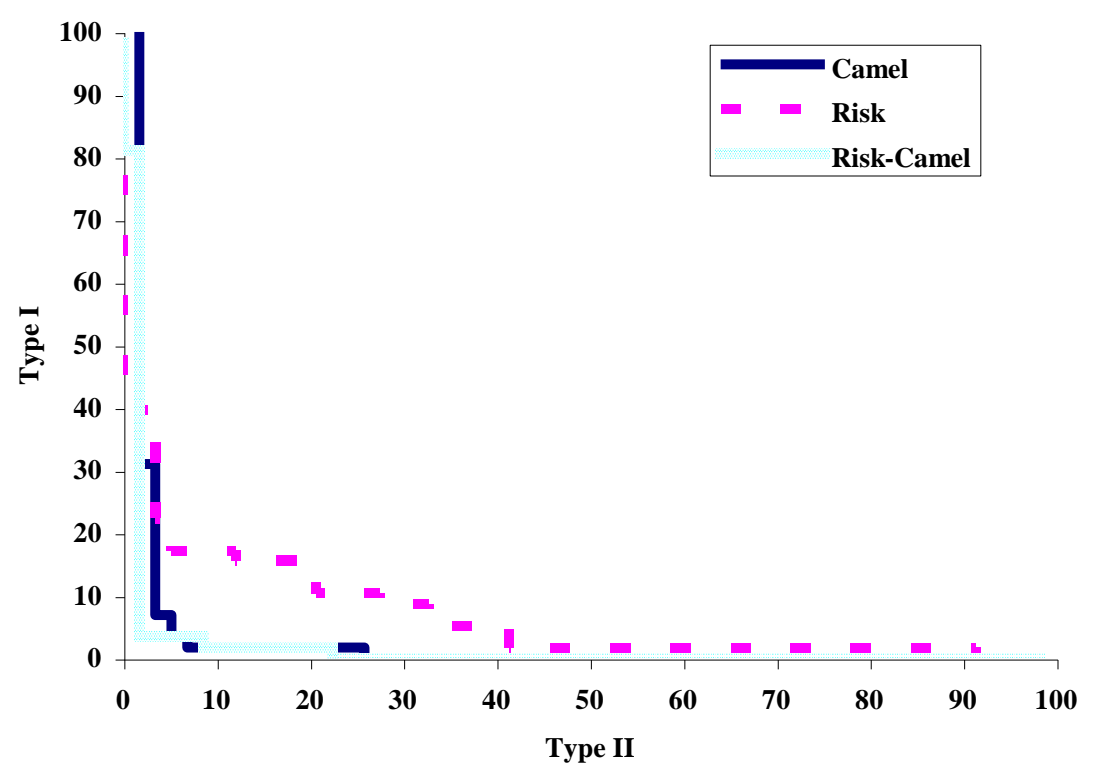

However, Figure 1 indicates superiority for the predictive accuracy of the CAMEL plus loan default measures (i.e., the Risk-Camel) model in comparison to either of the other two models at the varying levels of risk.

\section{Regional Models}

As the CAMEL plus loan default model exhibits superior predictive ability, regional equations are presented for these expanded models for the four regions (Southwest, Midwest, Rocky Mountain and Southeast). Due to missing data and small sample sizes, models could not be estimated for two of the regions (Northeast and West). Table 5 presents results indicating loan default measures continue to exhibit information content in the prediction of failure. 
Table 5: Logit Model with CAMEL and Loan Default Measures For Regions

\begin{tabular}{|c|c|c|c|c|}
\hline Variable & $\begin{array}{c}\text { Coefficient } \\
\text { Region } 1\end{array}$ & $\begin{array}{c}\text { Coefficient } \\
\text { Region } 2 \\
\end{array}$ & $\begin{array}{c}\text { Coefficient } \\
\text { Region } 3 \\
\end{array}$ & $\begin{array}{c}\text { Coefficient } \\
\text { Region } 4 \\
\end{array}$ \\
\hline CAPAD & $\begin{array}{c}-2.004 \\
(.000)\end{array}$ & $\begin{array}{l}-.636 \\
(.000)\end{array}$ & $\begin{array}{l}-.892 \\
(.000)\end{array}$ & $\begin{array}{l}-.494 \\
(.226)\end{array}$ \\
\hline AA & $\begin{array}{c}.033 \\
(.051)\end{array}$ & $\begin{array}{l}.019 \\
(.006)\end{array}$ & $\begin{array}{c}.018 \\
(.217)\end{array}$ & $\begin{array}{l}-.130 \\
(.260)\end{array}$ \\
\hline MAN & $\begin{array}{l}.022 \\
(.310)\end{array}$ & $\begin{array}{l}-.014 \\
(.537)\end{array}$ & $\begin{array}{l}-.010 \\
(.586)\end{array}$ & $\begin{array}{l}-.103 \\
(.207)\end{array}$ \\
\hline EARN & $\begin{array}{l}-.595 \\
(.042)\end{array}$ & $\begin{array}{l}-.874 \\
(.001)\end{array}$ & $\begin{array}{l}.013 \\
(.963)\end{array}$ & $\begin{array}{l}-1.910 \\
(.356)\end{array}$ \\
\hline LIQUID & $\begin{array}{l}-.245 \\
(.001)\end{array}$ & $\begin{array}{l}-.099 \\
(.000)\end{array}$ & $\begin{array}{l}-.182 \\
(.005)\end{array}$ & $\begin{array}{l}-.117 \\
(.119)\end{array}$ \\
\hline PROV & $\begin{array}{l}.382 \\
(.374)\end{array}$ & $\begin{array}{l}-.100 \\
(.696)\end{array}$ & $\begin{array}{l}.209 \\
(.799)\end{array}$ & $\begin{array}{l}.567 \\
(.803)\end{array}$ \\
\hline $\mathrm{NCO}$ & $\begin{array}{l}.750 \\
(.060)\end{array}$ & $\begin{array}{l}.284 \\
(.235)\end{array}$ & $\begin{array}{l}.533 \\
(.397)\end{array}$ & $\begin{array}{l}-.042 \\
(.980)\end{array}$ \\
\hline PASTDUE & $\begin{array}{l}.995 \\
(.003)\end{array}$ & $\begin{array}{l}.021 \\
(.483)\end{array}$ & $\begin{array}{l}.330 \\
(.285)\end{array}$ & $\begin{array}{l}1.286 \\
(.078)\end{array}$ \\
\hline NONACC & $\begin{array}{l}.710 \\
(.004)\end{array}$ & $\begin{array}{l}.070 \\
(.114)\end{array}$ & $\begin{array}{l}.473 \\
(.065)\end{array}$ & $\begin{array}{l}-.002 \\
(.994)\end{array}$ \\
\hline RES & $\begin{array}{l}-.672 \\
(.201)\end{array}$ & $\begin{array}{l}.205 \\
(.376)\end{array}$ & $\begin{array}{l}-.393 \\
(.648)\end{array}$ & $\begin{array}{l}1.112 \\
(.172)\end{array}$ \\
\hline Constant & $\begin{array}{l}16.060 \\
(.001)\end{array}$ & $\begin{array}{l}7.541 \\
(.000)\end{array}$ & $\begin{array}{l}10.273 \\
(.006)\end{array}$ & $\begin{array}{l}6.588 \\
(.119)\end{array}$ \\
\hline & $\mathrm{CA}=96.6$ & $\mathrm{CA}=91.6$ & $\mathrm{CA}=97.0$ & $\mathrm{CA}=98.8$ \\
\hline & $\mathrm{N}=268$ & $\mathrm{~N}=310$ & $\mathrm{~N}=135$ & $\mathrm{~N}=94$ \\
\hline
\end{tabular}

$\begin{array}{lll}\text { CAPAD } & = & \text { (Equity Capital + loan loss reserves)/total assets x } 100 \\ \text { AA } & = & \text { Commercial and industrial loans/total loans x 100 } \\ \text { MAN } & = & \text { Percent change in loans during the past 5 years } \\ \text { EARN } & = & \text { Income before securities gains \& losses/average total assets x 100 } \\ \text { LIQUID } & = & \text { [(Total assets-total loans)/total assets] x 100 } \\ \text { PROV } & = & \text { Loan loss provision /average loans x 100 } \\ \text { NCO } & = & \text { Net charge-offs of loans/average loans x 100 } \\ \text { PASTDUE } & = & \text { Loans 90 days or more past due/total loans x 100 } \\ \text { NONACC } & = & \text { Loans where interest is no longer accrued/total loans x } 100 \\ \text { RES } & = & \text { Loan loss reserve/total loans x 100 } \\ \text { REGION 1 } & = & \text { Southwest } \\ \text { REGION 2 } & = & \text { Midwest } \\ \text { REGION 3 } & = & \text { Rocky Mountain } \\ \text { REGION 4 } & = & \text { Southeast } \\ \text { CA } & = & \text { Correct classification accuracy }\end{array}$

Past due (PASTDUE) and non-accruing (NONACC) loans in Table 5 display significance more consistently over the four regions than the other loan default risk measures. Chi-square test statistics for differences with the addition of the loan default measures to the CAMEL models were .000 (Southwest), .110 (Midwest), .008 (Rocky Mountain) and .198 (Southeast).

In testing the general model, net charge-offs (NCO) exhibit significance in the loan default model. For the regional model, net charge-offs exhibit significance at a .06 level in the Southeast region. Of all the prior bank failure studies, only the Kocagil et al. (2002) results support the usefulness of net charge-offs.

Loan loss provisions (PROV) and loan loss reserves (RES) did not exhibit significance in any of the regional models. Both of these variables may be affected by a significant level of managerial discretion and thus had the highest possibility of containing "noise" in relaying the managers' views. 
For the Southeast (Region 4), only a loan default measure (PASTDUE) displays significance at an alpha lower than .1. An explanation for the usefulness of a loan default measure in the Southeast arises from the high proportion of real estate loans in the declining real estate market in the early 1990's. In addition, the change in the real estate market may have developed so rapidly that the capital adequacy measure did not have time to capture the change and therefore did not signal the problem. The loan default risk measure appears to encapsulate the change more effectively.

Further tests were performed to examine the predictive ability of the regional models from the Southwest region for one period ahead. Generally, the results for the out of sample regional predictions exhibited superior results in comparison with those of the earlier models in this present study. For example, for the CAMEL plus loan default measures model the classification accuracy increased from a general classification accuracy of $93.2 \%$ for the entire sample (Table 3) to $98.8 \%$ for the Southeast (Region 4), as shown in Table 5. The results provide support for hypothesis three.

Figure 2 provides a graph of the trade off in error types, which supports the contention that the loan default measures contain unique information by region.

Figure 2: TradeOff In Error Types For Holdout Sample With Region Coefficients

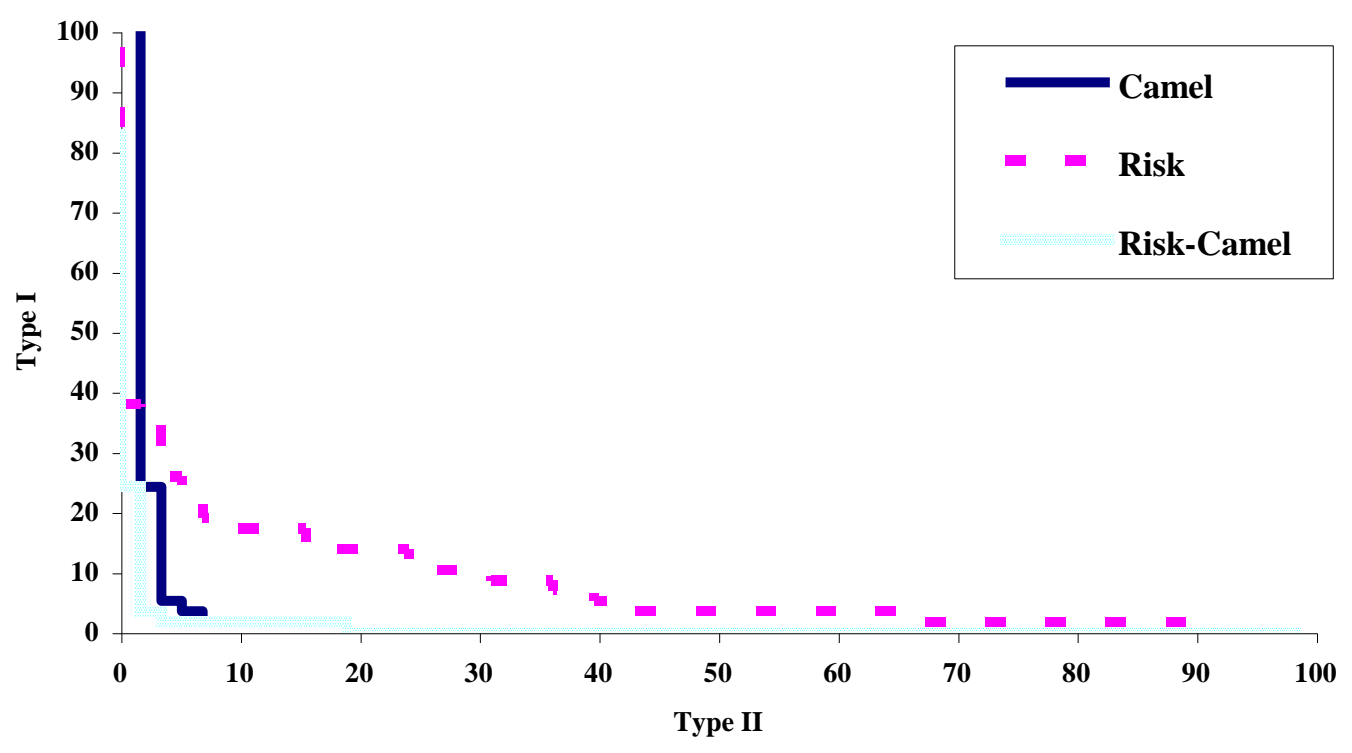

The location of the errors from both the CAMEL and the CAMEL plus loan default (Risk-Camel) regional model indicates lower errors and exhibits a higher curvature compared to the errors in Figure 1 for the general model. For example, at a 5\% Type II error rate the general CAMEL model exhibits a Type I error rate of $6.9 \%$, while the regional CAMEL model yields a lower Type I error rate of $3.45 \%$.

For the general expanded CAMEL plus loan default measures model, a Type II error rate of 5\% accompanies a Type I error rate of $3.45 \%$, while the regional expanded model exhibits a decreased Type I error rate of $1.72 \%$.

\section{CONCLUSIONS}

The present study provides supportive theory, evidence and substantiation through statistical analyses to support the contention of predictive ability in loan default measures. Loan default risk measures exhibit information not only singly, but also incrementally. The results of the analysis support and extend prior research to indicate that 
past due loans, loan loss provisions, non-accruing loans and net charge-offs provide significant information for prediction of bank failure.

Regional models provide improved classification accuracy for bank failure prediction with provision of commonly lower Type I and Type II errors. Not only did the regional models provide higher classification accuracy, but also interestingly the capital adequacy measure did not display significance in all of the regional models. In contrast, in the model where capital adequacy displayed no significant explanatory power, a loan default measure assisted in predictions.

\section{REFERENCES}

1. Akhigbe, A. and Whyte, A. M. Changes in market assessments of bank risk following the Riegle-Neal Act of 1994. Journal of Banking and Finance 27 (2003), 87-102.

2. Altman, E. I. A Further Empirical Investigation of the Bankruptcy Cost Question. The Journal of Finance (September) (1984), 1067-1089.

3. Amos, Jr., O. M. The Regional Distribution of Bank Closings in the US from 1982 to 1988. Southern Economics Journal 58(3) (1992), 805-815.

4. Azcentral.com/news/articles/0407nextbank07.html.

5. Barth, J. R., Bartholomew, P. F., and Bradley, M. G. Determinants of Thrift Institution resolution costs. Journal of Finance 45(3) (1990), 731-754.

6. Barth, M. E., Beaver, W. H., and Landsman, W. R. Value-Relevance of Banks' Fair Value Disclosures Under SFAS No. 107. The Accounting Review 71(4) (1996), 513-537.

7. Beaver, W. H., Eger, C., and Ryan, S., et al. Financial Reporting, Supplemental Disclosures and Bank Share Prices. Journal of Accounting Research 27(2) (1989), 151-178.

8. Beaver, W. H., and Engel, E. E. Discretionary Behavior with Respect to Allowances for Loan Losses and the Behaviour of Security Prices. Journal of Accounting and Economics 22(3) (1996), 177-206.

9. Berger, A. N., King, K. K., and O'Brien. The limitations of market value accounting and a more realistic alternative. Journal of Banking and Finance 15 (1991), 753-783.

10. Berger, A. N., Herring, R. J., and Szegö, G. P. The role of capital in financial institutions. Journal of Banking and Finance 19 (1995), 393-430.

11. Bloomberg News. Regulator predicts increase in bank failures. Indianapolis Business Journal (May) (2001), 24.

12. Cantor, R. Moody's investors' service response to the consultative paper issued by the Basle Committee on Bank Supervision A new capital adequacy framework. Journal of Banking and Finance 25 (2001), 171-185.

13. Cole, R. A., Cornyn, and Gunther, J. W. A new monitoring system for banking institutions. Federal Reserve Bulletin 81 (1995), 1-15.

14. Cole, R. A. and Gunther, J. W. Separating the likelihood and timing of bank failure. Journal of Banking and Finance 19 (1995), 1073-1089.

15. Cole, R. A. and Gunther, J.W. Predicting Bank Failures: A Comparison of On- and Off-Site Monitoring Systems. Journal of Financial Services Research 22(1) (1998), 103-117.

16. Eccher, E. A., Ramesh K., and Thiagarajan S. R. Fair value disclosures by bank holding companies. Journal of Accounting and Economics 22(1) (1996), 79-117.

17. Elliott, J. A., Douglas, H. L. J., and Shaw, W. H. The Evaluation by the Financial Markets of Changes in Bank Loan Loss Reserve Levels. The Accounting Review 66(4) (1991), 847-861.

18. Espahbodi P. Identification of problem banks and binary choice models. Journal of Banking and Finance 15(1) (1991), 53-71.

19. FDIC.gov/news/press/2002.

20. $\quad$ FDICG.gov/reports04/04-004 (2004).

21. Griffin, A. Further Evidence on the Economic Effects of Changes in Loan Loss Provisions on Bank Stock Returns. Abacus 34(2) (1998), 188-203.

22. Griffin, A. and Wallach, S. J. R. Latin American Lending by Major U.S. Banks: The Effects of Disclosures about Nonaccrual Loans and Loan Loss Provisions. The Accounting Review 66(4) (1991), 830-846.

23. Kocagil A.E., Reyngold A., and Stein R.M. Moody's RiskCalc Model For Privately-Held U.S. Banks. 
Moody's Investors Service (July) (2002), 1-27.

24. Kolari, J., Glennon, D., and Shin, H. Predicting large U.S. commercial bank failures. Journal of Economics and Business 54 (2002), 361-387.

25. Krause, S., Graham, F. C., and Horner, J. E. An Evaluation of the Factors Contributing to the Failure of National Banks (Staff study, Office of the Comptroller of the Currency); cited in a speech by R. L. Clarke, Comptroller of the Currency before the Exchequer Club, Washington, D.C., (1988), January 20.

26. Lane, W. R., Looney, S. W., and Wansley J. W. An Application of the Cox Proportional Hazards Model to Bank Failure. Journal of Banking and Finance 10(4) (1986), 511-531.

27. Lee, J., Li K. On Recensoring For Censored Paired Data. Journal of the American Statistical Association 88(1) (1993), 104-119.

28. Liu, C. and Ryan, S. G. The Effect of Bank Loan Portfolio Composition on the Market Reaction to and Anticipation of Loan Loss Provisions. Journal of Accounting Research 33(1) (1995), 77-94.

29. Liu, C., Ryan, S. G., and Wahlen, J. M. Differential Valuation Implications of Loan Loss Provisions Across Banks and Fiscal Quarters. The Accounting Review 72(1) (1997), 133-146.

30. Looney, S. W., Wansley, J. W., and Lane, W. R. An Examination of Misclassifications with Bank Failure Prediction Models. Journal of Economics and Business 41(4) (1989), 327-336.

31. Marini, F. Bank Insolvency, Deposit Insurance and Capital Adequacy. Journal of Financial Services Research 24(1) (2003), 66-78.

32. Martin, D. Early warnings of bank failure: a logit regression approach. Journal of Banking and Finance 1(4) (1977), 249-276.

33. Meyer, P. A. and Pifer, H. W. Prediction of Bank Failures. Journal of Finance 25(4) (1970), 853-868.

34. Milne, A. Bank capital regulation as an incentive mechanism: Implications for portfolio choice. Journal of Banking and Finance 26(1) (2002), 1-23.

35. Mingo, J.J. Policy implications of the Federal Reserve study of credit risk models at major US banking institutions. Journal of Banking and Finance 24 (2000), 15-33.

36. Neter, J., Wasserman, W., and Kutner, M. Applied Linear Statistical Models. Homewood, Illinois: Irwin Publishing, $2^{\text {nd }}$ edition, 1985.

37. Norusis, M. SPSS Advanced Statistics User's Guide. Chicago, Illinois: SPSS Inc., 2002.

38. Pettway, R. W., and Sinkey, Jr., J. F. Establishing On-Site Bank Examination Priorities: An Early-Warning System Using Accounting and Market Information. Journal of Finance 35(1) (1980), 137-150.

39. Sinkey, Jr., J. F. A Multivariate Statistical Analysis of Characteristics of Problem Banks. Journal of Finance 30(1) (1975), 21-36.

40. Sinkey, Jr., J. F. Identifying 'Problem' Banks: How Do the Banking Authorities Measure A Bank's Risk Exposure? Journal of Money and Credit 10 (1978), 184-193.

41. Sudarsanam, P. S. and Taffler, R. J. Financial ratio proportionality and inter-temporal stability: An empirical analysis. Journal of Banking and Finance 19 (1995), 45-60.

42. Sundaresan, S.M. Supervisor and Market Analysts: What Should Research be Seeking. Journal of Financial Services Research 20 (2/3) (2001), 275-280.

43. Tam, K. and Kiang, M. Y. Managerial Applications of Neural Networks: The Case of Bank Failure Predictions. Management Science 38(7) (1992), 926-947.

44. Thomson, B. Predicting Bank Failures in the 1980s. Economic Review (1991), 9-20.

45. Wagster, J.D. The Basle Accord of 1988 and the International Credit Crunch of 1989-1992. Journal of Financial Services Research 15(2) (1999), 123-143.

46. Wahlen, M. The Nature of Information in Commercial Bank Loan Loss Disclosures. The Accounting Review 69(3) (1994), 455-478.

47. West, R. A Factor-Analytic Approach To Bank Condition. Journal of Banking and Finance 9(2) (1985), 253266.

48. Whalen, G. A Proportional Hazards Model of Bank Failure: An Examination of Its Usefulness as an Early Warning Tool. Federal Reserve Board Bank of Cleveland, Economic Review 27(1) (1991), 21-31.

49. Whalen, G., Thomson J. B. Using Financial Data to Identify Changes in Bank Conditioning. Federal Reserve Bank of Cleveland. Economic Review 24(1) (1988), 17-26. 


\section{Appendix A}

\section{CAMEL Model}

Capital adequacy:

$\overline{\mathrm{CAPAD}}=$ (Equity capital + loan loss reserves)/total assets $\mathrm{x} 100$

\section{Asset quality:}

$\mathrm{AA}=$ Commercial and industrial loans/total loans $\mathrm{x} 100$

\section{Management:}

MAN $=$ Percent change in loans during the past 5 years

\section{Earnings:}

EARN $=$ Income before securities gains and losses/average total assets $\mathrm{x} 100$

\section{Liquidity:}

$\underline{\text { LIQUID }}=[($ Total assets-total loans $) /$ total assets $] \times 100$

\section{Definitions: Loan Default Measures}

PROV: $\quad$ The category of loan loss provision provides the amount of loss recognized in the current year, where the amount is probable and reasonably estimable by bank management. Discretion exists in this amount, especially as to the timing due to associated tax savings.

NCO: $\quad$ Net charge-offs measure the net amount of loans written off during the year less the recovery of any previously written off loans. These loan write-offs are considered less discretionary, as they are normally adjudged based on consideration of the time period the loan has been outstanding and deemed delinquent.

PASTDUE: Loans whose payments are 90 days or more past due, but interest is still accruing on the loans.

NONACC: Non-accruing loans occur when the cash basis is applied for interest income because of substantial uncertainty as to the collectibility (normally at least 90 days delinquent).

RES: $\quad$ The loan loss reserve (allowance for loan losses) category reports the amount for the balance sheet account used to reduce the loan receivable balance to its estimated collectible value. 


\section{NOTES}

